DOI https://doi.org/10.15589/znp2019.3(477).9

УДК 338.242.2: 339.976 .2

\title{
COMPARATIVE ANALISIS OF APPROACHES TOWARDS IMPLEMENTATION OF COMPATITIVE STRATEGIES IN DIFFERENT COUNTRIES
}

\author{
КОМПАРАТИВНИЙ АНАЛІЗ ПІДХОДІВ ДО РЕАЛІЗАЦЇ̈ \\ КОНКУРЕНТНИХ СТРАТЕГІЙ РІЗНИМИ КРАЇНАМИ СВІТУ
}

\author{
Uliana V. Shchurko \\ u.shchurko@Inam.edu.ua \\ ORCID: 0000-0002-3646-1111
}

\author{
У. В. Щурко, \\ канд. екон. наук, доцент
}

Lviv National Academy of Arts, Lviv

Львівська начіональна академія мистецтв, Львів

\begin{abstract}
Globalization and mega-regionalization processes, covering more and more countries around the world, challenged them to find ways to strengthen their competitiveness to protect their own interests and niche in the global market. Developing a system and logic for creating competitive advantages leads to the formation of an economic development strategy, which, however, in view of the rapid nature of socio-political processes in the modern world, requires constant improvement and renewal. The purpose of the article is to highlight the specific competitive features of the strategies of the leading world countries with the characteristics of their key positions to make recommendations for improving the Ukrainian competitive strategy. Based on the analysis of the models that formed the basis for the development of the strategies, countries were grouped by types that conformed to the principles of these models. The use of comparative analysis as a method, as well as generalization and comparison, has made it possible to prioritize the areas of development, spheres and sectors of the economy whose development provides leadership in the global economic market. The analysis of the latest economic strategies of the United States, Germany and Japan has made it possible to formulate a list of directions, the development of which will enhance the competitiveness of the Ukrainian economy. The novelty of the work is the use of primary sources and the latest foreign studies on the current state of implementation of strategies developed during the reign of US President Donald Trump, German Chancellor Angela Merkel and Japanese Prime Minister Shinzo Abe to develop proposals for improving the national strategy. The results of the study can be applied at different levels of the hierarchy of government - national, regional and local - to formulate economic development priorities, develop programs and concepts that will form the basis of Ukraine's latest economic development strategy.
\end{abstract}

Key words: models; strategies; economic development; competitive advantage; competitiveness.

Анотація. Процеси глобалізації та мега-регіоналізації, що охоплюють дедалі більше країн світу, ставлять перед ними завдання пошуку шляхів зміцнення конкурентоспроможності для відстоювання власних інтересів та ніші на світовому ринку. Вироблення системи та логіки створення конкурентних переваг спонукає до формування стратегії економічного розвитку, яка, проте, зважаючи на швидкоплинність суспільно-політичних процесів у сучасному світі, потребує постійного удосконалення та оновлення. Метою статті $є$ виокремлення специфічних конкурентних рис стратегій провідних країн світу з характеристикою їх ключових позицій для вироблення рекомендацій з удосконалення української конкурентної стратегії. На основі аналізу моделей, що лягли в основу розробки стратегій, було здійснено групування країн за типами, які відповідали принципам цих моделей. Використання компаративного аналізу як методу, а також узагальнення та порівняння, забезпечило можливість пріоритизації напрямів розвитку, сфер і галузей економіки, розвиток яких забезпечує лідерство на глобальному економічному ринку. Аналіз новітніх економічних стратегій Сполучених Штатів, Німеччини та Японії дав змогу сформувати перелік напрямів, розвиток яких забезпечить посилення конкурентоспроможності української економіки. Новизною роботи $є$ використання першоджерел і найновіших іноземних досліджень про сучасний стан втілення стратегій, розроблених за часів правління президента США Д. Трампа, канцлера ФРН А. Меркель та прем'єр-міністра Японії Ш. Абе, для розробки пропозицій удосконалення вітчизняної стратегії економічного розвитку. Результати дослідження можуть застосовуватися на різних рівнях ієрархії управління національному, регіональному та локальному - для формування пріоритетів економічного розвитку, розробки програм та концепцій, що лягатимуть в основу новітньої стратегії економічного розвитку України.

Ключові слова: моделі; стратегії; економічний розвиток; конкурентна перевага; конкурентоспроможність. 


\section{ПОСТАНОВКА ЗАДАЧІ}

Зростання масштабів і динаміки міжнародного руху факторів виробництва, технологій, інновацій, інформації розкриває всю багатовимірність глобалізаційних процесів, що залишають свій відбиток на кожній країні. Цей вплив неоднорідний і не завжди позитивний, оскільки сама глобалізація не є гомогенною та прямолінійною, а переваги розподіляються нерівномірно та непропорційно між державами $[1$, c. 5]. Соціально-економічний розрив між країнами - глобальними лідерами та аутсайдерами зростає, насамперед, на основі відставання у створенні та освоєнні технологічних інновацій в інформаційному суспільстві.

Зважаючи на соціокультурні відмінності між країнами та регіонами, глобалізація виступає джерелом та стимулом конкуренції, відкриваючи нові можливості розвитку, і водночас провокує кризи та конфлікти локального та цивілізаційного масштабу.

Для згладжування відмінностей та розривів у розвитку та цивілізаційному русі країни розробляють стратегії розвитку на основі найновітніших технологій для збереження лідерства або завоювання нових ринків.

\section{АНАЛІЗ ОСТАННІХ ДОСЛІДЖЕНЬ I ПУБЛІКАЦІЙ}

Зв'язок рівня розвитку економіки зі стадіями розвитку цивілізації (за переважаючим типом господарювання: аграрний, індустріальний, постіндустріальний) прослідковується за секторальними частками: сільського господарства, промисловості та послуг - у галузевій структурі економіки, що розраховується як частка (1) вартості продукції чи послуг у ВВП або (2) зайнятих у галузі щодо усіх зайнятих в економіці. Більшість країн світу знаходиться на індустріальній i постіндустріальній стадії розвитку: у 2018 р. послуги становили 22,4\% світового обороту торгівлі товарами і послугами, а в 2010 р. - 19,6\%, що підтверджує їхню зростаючу частку у світовій торгівлі [2]. У 2017 p. сектор послуг становив $63 \%$ від світового ВВП (за паритетом купівельної спроможності). У табл 1. подано дані секторальної пропорції глобальної економіки, ЄС та США.

Проте, на думку Ю. Козака та ін., сам по собі показник частки послуг у ВВП країни є недостатнім для ствердження про іiі перехід на найвищих щабель еко- номічного розвитку - часто він має кількісний, а не якісний вимір [4, с. 25]. Так, наприклад, частка сфери послуг у ВВП Барбадосу у 2017 р. становила 88,7\%, що не може виступати підтвердженням високого рівня конкурентоспроможності країни чи їі економічного розвитку (Багамські острови - 90\%, Мальдіви $81 \%$, Монако - 86\%: конкурентна перевага за рахунок розвитку туризму, офшорної зони чи специфічної сфери гральних послуг) [5].

Стратегії розвитку економіки країни великою мірою базуються на моделях економічного розвитку, притаманного конкретній країні. В. Ломакін виокремлює розподіл групи розвинених країн за основними моделями, що лежать в основі формування економічної стратегії, на (1) ліберальну, (2) корпоративістську та (3) соціально-ринкову (рис. 1) [6].

В. Ковалевський, Ю. Козак та ін. окреслюють ключову рису ліберальної моделі розвитку як мінімальне втручання урядових структур у механізм взаємодії підприємців і найманих працівників. Корпоративістська модель передбачає активну роль держави в регулюванні соціально-економічних відносин й високий рівень соціального партнерства між робітниками й роботодавцями. Ця модель має два різновиди: демократичний та ієрархічний корпоративізм. Модель демократичного корпоративізму найбільш поширена в скандинавських країнах, особливо в Швеції. Ієрархічний корпоративізм притаманний Японії, тому він одержав ще назву японської моделі. Її характерною особливістю є активне втручання уряду в економічне регулювання при незначній частці державної власності в економіці. Соціально-ринкова модель розвитку найбільш характерна для Німеччини. Важливою iii рисою є підтримка малозабезпечених верст населення й загалом потребуючих [4, с. 129-131].

\section{ВІДОКРЕМЛЕННЯ НЕ ВИРІШЕНИХ РАНІШЕ ЧАСТИН ЗАГАЛЬНОӤ ПРОБЛЕМИ}

Глобалізаційні процеси стимулюють усі країни до пошуку нових шляхів зміцнення конкурентоспроможності. Найшвидше на ці виклики реагують країни-лідери, а Україна найчастіше керується підходами, апробованими раніше, задля вироблення інструментарію формування конкурентної позиції. Тому саме питанням пріоритетності формування національної конкурентної стратегії в унісон зі стратегіями передових країн світу приділено увагу в цьому дослідженні.

Таблиця 1. Розподіл часток у ВВП (за ПКС) за секторами економіки, 2017 р. (\% та млн дол. США)

\begin{tabular}{|c|c|c|c|c|c|c|c|}
\hline Країна Іекономіка & $\begin{array}{c}\text { ВВП } \\
\text { (млн дол США) }\end{array}$ & \multicolumn{2}{|c|}{$\begin{array}{c}\text { Сільське } \\
\text { господарство }\end{array}$} & \multicolumn{2}{|c|}{ Промисловість } & \multicolumn{2}{|c|}{ Послуги } \\
\hline Світ & 127800000 & $6,4 \%$ & 8179200 & $30,0 \%$ & 38340000 & $63,0 \%$ & 80514000 \\
\hline Свропейський Союз & 20850000 & $1,6 \%$ & 333600 & $25,1 \%$ & 5233350 & $70,9 \%$ & 14782650 \\
\hline $\begin{array}{c}\text { Сполучені Штати } \\
\text { Америки }\end{array}$ & 19490000 & $0,9 \%$ & 175410 & $19,1 \%$ & 3722590 & $80,0 \%$ & 15592000 \\
\hline
\end{tabular}

Складено за: [3] 


\section{ЕКОНОМІКА ТА МЕНЕДЖМЕНТ № 3-2019}

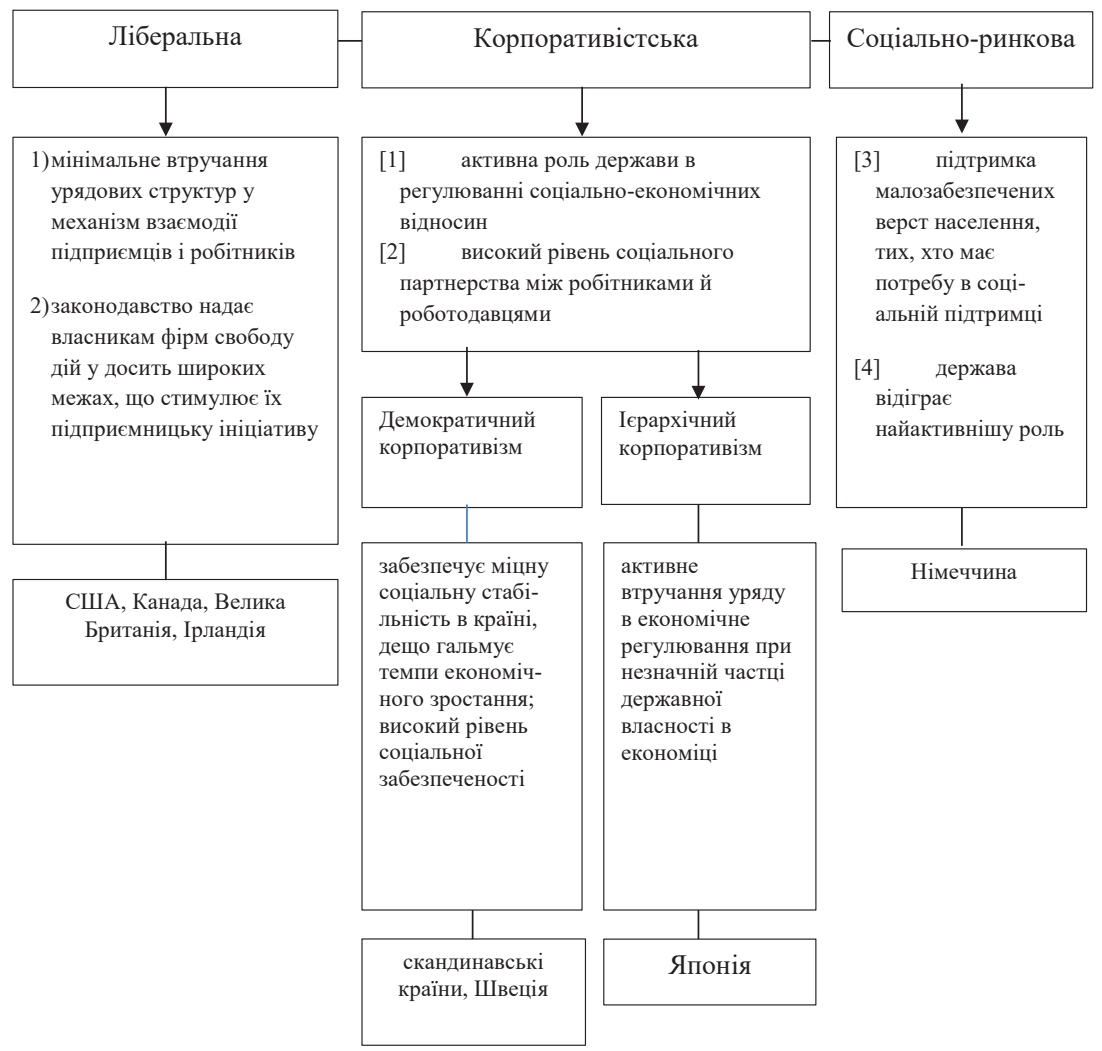

Рис. 1. Характеристики моделей економічного розвитку як основ побудови стратегії

\section{МЕТА ДОСЛІДЖЕННЯ}

Метою статті є виокремлення специфічних конкурентних рис стратегій провідних країн світу з характеристикою їх ключових позицій для вироблення рекомендацій $з$ удосконалення української конкурентної стратегії.

\section{МЕТОДИ, ОБ'ЄКТ ТА ПРЕДМЕТ ДОСЛІДЖЕННЯ}

Проведене дослідження грунтується на використанні компаративного аналізу, узагальненні статистичних даних і відомостей, отриманих за допомогою неформального контент-аналізу із відкритих джерел інформації - вітчизняних і закордонних. Об'єктом дослідження обрано процеси формування новітніх стратегій розвитку, які відбуваються в провідних країнах світу. Предмет - методологічні та прикладні аспекти розробки стратегій економічного розвитку країн для забезпечення їх конкурентоспроможності в сучасних глобальних умовах.

\section{ОСНОВНИЙ МАТЕРІАЛ}

Уряд Сполучених штатів реалізовує економічну політику на основі ліберальної моделі. Сучасна стратегія розвитку держави в США також побудована 3 опорою на цю модель, а ії тяглість бере початок у 1970-х рр. На зламі століть у країні відбулися суттеві зміни: ще в 1950-х рр. в обробній промисловості працювало 30\% зайнятих, а на початку XXI ст. - 12\% [7] (у 2009 р. частка промисловості США становила $21,9 \%$ у ВВП, послуг - 76,9\%). Відбувся перехід до інформаційної економіки з використанням «деіндустріалізації» та «делокалізації», коли зріс попит на висококваліфіковану робочу силу розумової праці за одночасної масової перекваліфікації робітників переробної промисловості.

Розроблена в 2015 р. Інноваційна стратегія [8] пропонує механізми підвищення ефективності роботи приватного сектору та формування «нації інноваторів» (рис. 2).

3 обранням президентом США Д. Трампа в 2017 р. економічна політика країни зазнала чергового переформатування: «економічний націоналізм» Д. Трампа виводить інтереси країни понад інтереси світової спільноти. Це прослідковується і в екологічних ініціативах (відмова від дотримання Паризької кліматичної угоди, що передбачала скорочення викидів парникових газів, де частка США становить 20\% від світового обсягу викидів [9]), і в зовнішньоекономічному курсі (повернення до політики меркантилізму, 3 пропагуванням протекціонізму), і в участі в міжнародних об'єднаннях (23.01.2017 p. було проголошено відмову від подальших переговорів у форматі Трансатлантичного партнерства, зміни до умов функціонування NAFTA (ПАУВТ)) [10]. 


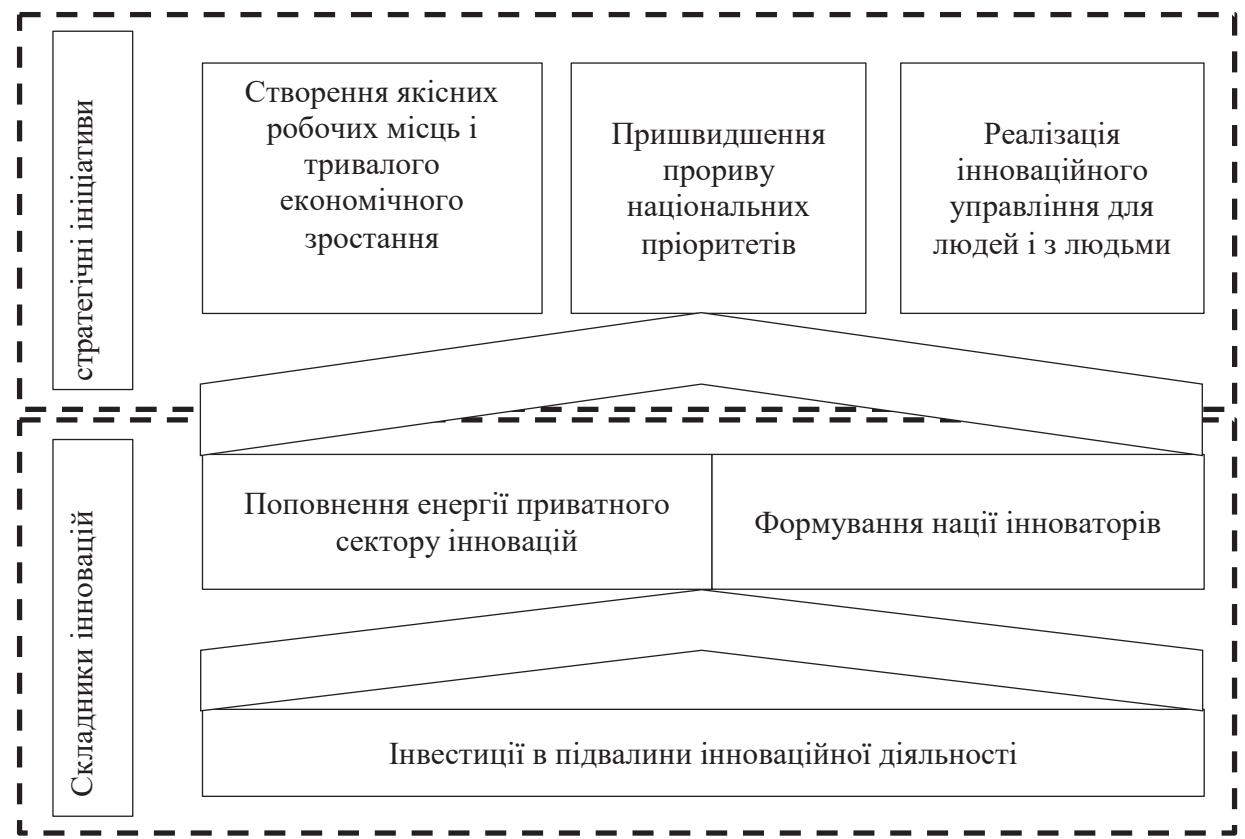

Рис. 2. Пріоритети інноваційної стратегії США 2015 року

Складено за: [8]

\section{ОБГОВОРЕННЯ ОТРИМАНИХ РЕЗУЛЬТАТІВ}

У 2018 р. Міністерство торгівлі США розробило економічну стратегію країни у відповідь на зміни глобального конкурентного середовища, з метою прискорення економічного зростання та посилення позиції США у світі. У Стратегії робиться акцент на інноваціях, поглиблюючи не лише дослідження штучного інтелекту, квантових обчислень, удосконалюючи захист інтелектуальної власності, але й вивчення комерційних можливостей освоєння космосу та аквакультури. Пріоритетом визнано формування законодавства для забезпечення вільної, справедливої та взаємної торгівлі з розширенням можливостей експортування товарів і послуг з США.

Розвиток передових технологій і системи безпеки визнано основними завданнями інноваційної стратегії: утримання лідерства в технологіях нового покоління, кібербезпеки, захисту даних, технологіях шифрування, впровадження мережі громадської безпеки та ін. Пріоритетними визнано такі цілі [11, с. 3-28]:

1) зміцнити американське лідерство в різних галузях;

2) стимулювати створення робочих місць;

3) посилити економічну та національну безпеку Сполучених Штатів;

4) дотримуватися конституційних вимог і забезпечувати економічну діяльність

5) впроваджувати клієнтоцентричну модель надання послуг найвищої якості.

Особливою рисою економічного розвитку США $€$ велика сконцентрованість країни на зовнішньоеко- номічній політиці та міжнародних стосунках. Така зацікавленість пояснюється не лише турботою про світове співтовариство, а насамперед про власний добробут, що великою мірою залежить від успішності та стабільності інших країн. Так, стратегією економічного розвитку на 2018-2022 рр. передбачено: (1) мобілізацію нових інвесторів для секторів та територій, що слабо розвиваються, створення робочих місць, нових економічних можливостей та розширення доступу та якості послуг - від фінансових та енергетичних до охорони здоров'я та освіти; (2) надання країнам доступу до ринків, де вони можуть продавати свої товари і послуги та розвивати власні економіки; (3) підвищення ефективності урядів у структуруванні грошових потоків, збільшення інвестицій та забезпечення вищої якості послуг; (4) вдосконалення інфраструктури (дороги, мости, водопостачання, електромережі), що $є$ критичним для подолання обмежень в економічному зростанні країни; (5) стимулювання економічного розвитку у сфері співпраці з компаніями приватного сектору, щоб залучати громадян до процесу економічного зростання; (6) залучення локальних каналів фінансування, надання змоги підприємцям у країнах, що розвиваються, покращувати якість життя [12].

Таким чином, програми економічного розвитку США також допомагають розширювати ринки для товарів і послуг, збільшуючи торгівлю та підтримуючи появу споживачів середнього класу, які можуть купувати американські товари та послуги. Оскільки стабільна економіка менш вразлива до криз, терористичної діяльності та міжнародної злочинності, США 
виводить пріоритетом міжнародної економічної стратегії допомогу в розвитку відсталим країнам.

Натомість зовсім інші особливості вирізняють модель економічної стратегії Японії. Серед ключових чинників, що визначають оригінальність японської моделі, є: (1) історико-економічні умови (самоізоляція Японії та готовність впроваджувати найновіші науково-технічні досягнення); (2) рішучість у проведенні економічних реформ; (3) специфіка соціальних відносин, зокрема, «уряд-бізнес-громадяни» [13].

Фінансова реформа під назвою «великий вибух» у 1999 р. усунула перешкоди для доступу на фінансові ринки: банки, брокерські й страхові компанії отримали змогу займатися всіма видами фінансових операцій; нефінансові компанії були допущені на фінансові ринки і дозволена торгівля цінними паперами поза фондовими біржами. Відбулася дерегуляція економіки, з обмеженням втручання держави в діяльність суб'єктів господарювання і зростанням ролі ринкових важелів. Пріоритетами нової економічної політики стали (1) дерегуляція економіки, (2) «вичищення» банківської системи від безнадійних боргів (що утворилися внаслідок лускання «мильної бульбашки») і (3) жорсткий контроль дефіциту бюджету.

Внаслідок лібералізації зовнішньоекономічної діяльності посилився приплив іноземних інвестицій, а тісне співробітництво в межах ОЕСР та зміцнення позицій в Азіатсько-Тихоокеанському регіоні $є$ головними пріоритетами зовнішньоекономічної політики Японії [13]. Подібно до США, Японія також робить акцент на високотехнологічних продуктах та комунікаційних послугах, за якими країна перебуває серед лідерів на світовому ринку.

Формування нових напрямів розвитку країни почалося з часу запровадження стратегії розвитку, розробленої з приходом на посаду прем'єр-міністра Ш. Абе у 2012 р. Очолюваний ним уряд запропонував концепцію відродження японської економіки після двох десятиліть дефляції. За прізвищем лідера програма економічного розвитку Японії отримала назву «Абеноміка» (рис. 3) і переросла в широкий план соціально-економічних змін для покращення добробуту усіх категорій: громадян, компаній, інвесторів та ін. [14].

Метою такої новітньої стратегії є стале економічне зростання, ключовими чинниками якого є зростання виробництва та доходів населення. Насамперед уряд ставить перед собою завдання підвищення заробітної плати через структурні реформи та підвищення рівня залучення інвестицій. Наступною потужною метою $є$ створення та підтримання умов для людиноцентричної економіки - «Суспільство 5.0». Така стратегія вже дає свої позитивні плоди: відповідно до звіту в Гамбурзі на Саміті G20 в 2017 р. [16], спостерігалося зростання реального ВВП протягом 1,5 р., збережено імпульс до досягнення цінової стабільності на рівні 2\%, протягом 2013-2017 рр. підвищення заробітної плати було на найвищому рівні від початку XXI ст., рівень безробіття становив 2,8\%, а коефіцієнт працевлаштування до поданих заявок - 1,48.

У Німеччині з приходом до влади християнських демократів на чолі з Ангелою Меркель в 2005 р. розпочався новий етап стратегічного розвитку. Рухаючись у напрямі формування постіндустріального суспільства, де великий акцент робиться на інформаційні, телекомунікаційні та інші новітні технології, Німеччина впроваджує в свою економічну модель стратегії розвитку різних секторів. Так, у листопаді 2018 р. три міністерства: (1) Федеральне міністерство освіти і досліджень, (2) з питань економіки та енергетики і (3) праці та соціальних питань - розробили Стратегію федерального уряду щодо штучного інтелекту (Ш, англ. Artificial Intelligence) [17].

Впровадженням цієї стратегії уряд встановлює основу для цілісної політики майбутнього розвитку та застосування Ш у Німеччині. 3 огляду на швидкий прогрес цих технологій та глобальні зміни у виробничих і цінових ланцюгах внаслідок нових технологій ШІ на основі досліджень та інновацій, довготерміновою метою уряду є формування Німеччини як центру досліджень штучного інтелекту.

Стратегічним завданням є розвиток технології Ш для застосування в чутливих сферах життя, в етичному, правовому, культурному та інституційному контексті, щоб вона служила на благо суспільства та окремої людини. Ключові моменти Стратегії були ухвалені урядом 18 липня 2018 р., а в 2020 р. іiі будуть адаптовувати під потреби цільових аудиторій і відповідно до найновіших розробок і вимог [18].

Для вдосконалення стратегії у федеральному бюджеті на 2019 р. було закладено 500 млн євро. До 2025 р. планується виділити близько 3 млрд євро на іiі реалізацію. Стратегія передбачає розвиток трьох ключових напрямів:

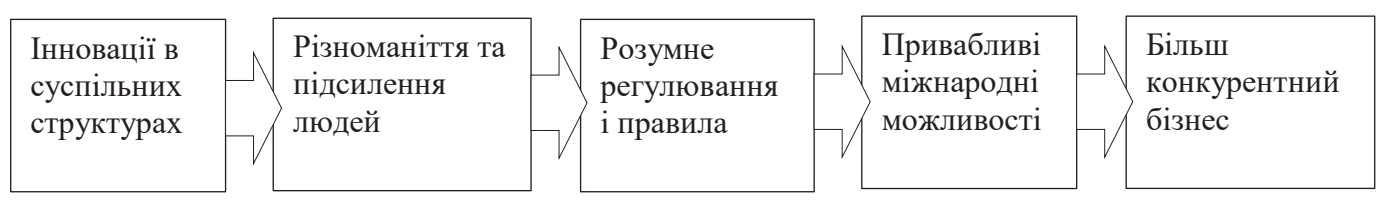

Рис. 3. Пріоритети економічної стратегії «Абеноміка» в Японії Складено за: [15] 
1) формування Німеччини як провідного центру ШІ і забезпечення конкурентоспроможності іiі економіки на майбутнє;

2) впровадження відповідального застосування ШІ для блага суспільства;

3) інтеграція Ш в суспільство $з$ дотриманням етичних, правових, культурних та інституційних норм у контексті широкого суспільного діалогу.

5 лютого 2019 р. Міністерство економіки та енергетики Німеччини презентувало новий стратегічний план розвитку промисловості - «Промислова стратегія 2030 - стратегічні вказівки для німецької та європейської промислової політики» [19], частиною якої є стратегія ШІ. Промислова стратегія 2030 має на меті забезпечити зростання доданої вартості промисловості до 25\%, підтримку МСП, промоцію промислового лідерства Німеччини на рівні країни, Свропи та світу, інвестиції в розвиток штучного інтелекту.

За підрахунками Німеччини, розвиток промисловості в напрямі новітніх технологій та зростання частки іiі доданої вартості у ВВП до $25 \%$ в країні та 20\% в Європі до 2030 р. - цілком реальна перспектива. При цьому втручання держави в цей процес буде мінімізовано, а ринок - максимально дерегульовано. Основний акцент робиться на (1) фундаментальних інноваціях та (2) темпах впровадження інновацій. Таким чином, стратегія посиленого інноваційного розвитку не лише запроваджена в Німеччині, але й просувається як основна для розвитку в інших країнах і в СС загалом.

\section{ВИСНОВКИ}

Аналіз новітніх економічних стратегій Сполучених Штатів, Німеччини та Японії дає змогу сформувати перелік напрямів, розвиток яких забезпечить посилення конкурентоспроможності української економіки. Такими напрямами повинні стати: 1) розвиток новітніх технологій, 2) формування інформаційного суспільства, на противагу індустріальному, 3) розвиток наукоємних галузей промисловості, 4) нарощування інвестицій у науково-дослідний сектор, 5) підтримка розвитку креативних індустрій, 6) формування виробництва продукції повного циклу, 7) використання пріоритетів стратегічного розвитку провідних країн світу для стимулювання розвитку високотехнологічних виробництв, 8) заохочення зростання частки сфери послуг і підвищення якості життя.

Результати дослідження можуть застосовуватися на різних рівнях ієрархії управління - національному, регіональному та локальному - для формування пріоритетів економічного розвитку, розробки програм та концепцій, що лягатимуть в основу новітньої стратегії економічного розвитку України.

\section{REFERENCES}

[1] Lukyanenko, D., Kalchenko, T. (2008) Stratehiyi hlobalnoho upravlinnya [Strategies of global government]. Mizhnarodna ekonomichna polityka. No 8-9. Pp. 5-42. [in Ukrainian]

[2] World trade in services. Eurostat. Retrieved from: https://ec.europa.eu/eurostat/statistics-explained/index.php/World_trade_ in_services

[3] GDP - composition, by sector of origin. The World Factbook. Central Intelligence Agency. Retrieved from: https://www.cia. gov/library/publications/download (10.12.2019)

[4] Kozak, Yu., Kovalevskyy, V., Zakharchenko, O. et al. (2011) Mizhnarodni stratehiyi ekonomichnoho rozvytku [International strategies of economics development]. Kiev : Avrio. 262 p. [in Ukrainian]

[5] GDP (purchasing power parity) The World Factbook. Central Intelligence Agency. Retrieved from: https://www.cia.gov/ library/publications/resources/the-world-factbook/fields/208.html (10.12.2019)

[6] Lomakin, V. (1999) Mirovaya ekonomika [World economy]. Moskva : Finansy. Pp. 352-356. [in Russian]

[7] Kalyadin, A. (2007) OON i prinuzhdeniye k nerasprastraneniyu OMU: opyt, vozmozhnosti, perspektivy [UNO and forcemeat to non-spreading weapons of mass destruction]. ME $i$ MO. No 4. P. 19. [in Russian]

[8] Olson, K. (2015) New White House Innovation Strategy Promotes Increase in Challenges and Prizes. Retrieved from: https:// digital.gov/2015/10/29/new-white-house-innovation-strategy-promotes-increase-in-challenges-and-prizes/

[9] Amadeo, K. (2019) President Donald Trump's Economic Plan The Balance. Retrieved from: https://www.thebalance.com/ donald-trump-economic-plan-3994106 (13.12.2019).

[10] Trump's NAFTA Changes. Retrieved from: https://www.thebalance.com/donald-trump-nafta-4111368.

[11] Helping the American economy grow. strategic plan | 2018-2022. U.S. Department of Commerce. 2018. 36 p.

[12] Economic growth and trade. Retrieved from: https://www.usaid.gov/what-we-do/economic-growth-and-trade 24.11.2019.

[13] OECD. Better policies for better lives. Retrieved from: http://www.oecd.org/

[14] Abenomics. For future growth, for future generations, and for a future Japan. Retrieved from: https://www.japan.go.jp/ abenomics/index.html

[15] Abenomics. JapanGov. The Government of Japan. Retrieved from: https://www.japan.go.jp/abenomics/

[16] Growth Strategy 2017. Japan. G20 Germany 2017. Hamburg. 30 June 2017. 15 p.

[17] Artificial Intelligence Strategy. Retrieved from: https://www.ki-strategie-deutschland.de/home.html

[18] Germany: Artificial Intelligence Strategy. European Commission. 9 April 2019. Retrieved from: https://ec.europa.eu/ knowledge4policy/publication/germany-artificial-intelligence-strategy_en

[19] Made in Germany: Die Industriestrategie 2030. Retrieved from: https://www.bmwi.de/Redaktion/DE/Dossier/ industriestrategie-2030.html 


\section{ЕКОНОМІКА ТА МЕНЕДЖМЕНТ № 3 2019}

\section{СПИСОК ВИКОРИСТАНОЇ ЛІТЕРАТУРИ}

[1] Лук'яненко, Д., Кальченко, Т. (2008). Стратегії глобального управління. Міжнародна економічна політика. № 8-9. С. 5-42.

[2] World trade in services. Eurostat. URL: https://ec.europa.eu/eurostat/statistics-explained/index.php/World_trade_in_services

[3] GDP - composition, by sector of origin. The World Factbook. Central Intelligence Agency. URL: https://www.cia.gov/ library/publications/download (10.12.2019)

[4] Козак, Ю. Г., Ковалевський, В. В., Захарченко, О. В. та ін. (2011). Міжнародні стратегії економічного розвитку: Навчальний посібник. Київ : Аврио. 262 с.

[5] GDP (purchasing power parity) The World Factbook. Central Intelligence Agency. URL: https://www.cia.gov/library/ publications/resources/the-world-factbook/fields/208.html (10.12.2019)

[6] Ломакин, В.К. (1999). Мировая экономика. Москва : «Финансы». С.352-356.

[7] Калядин, А. (2007). ООН и принуждение к нераспространению ОМУ: опыт, возможности, перспективы. МЭ и МО. №4. C. 19.

[8] Olson, K. (2015). New White House Innovation Strategy Promotes Increase in Challenges and Prizes. URL: https://digital. gov/2015/10/29/new-white-house-innovation-strategy-promotes-increase-in-challenges-and-prizes/

[9] Amadeo K. (2019). President Donald Trump's Economic Plan The Balance. URL: https://www.thebalance.com/donaldtrump-economic-plan-3994106 (13.12.2019)

[10] Trump's NAFTA Changes. URL: https://www.thebalance.com/donald-trump-nafta-4111368

[11] Helping the American economy grow. strategic plan | 2018-2022. U.S. Department of Commerce. 2018. 36 p.

[12] Economic growth and trade. URL: https://www.usaid.gov/what-we-do/economic-growth-and-trade (24.11.2019)

[13] OECD. Better policies for better lives. URL: http://www.oecd.org/

[14] Abenomics. For future growth, for future generations, and for a future Japan. URL: https://www.japan.go.jp/abenomics/ index.html

[15] Abenomics. JapanGov. The Government of Japan. URL: https://www.japan.go.jp/abenomics/

[16] Growth Strategy 2017. Japan. G20 Germany 2017. Hamburg. 30 June 2017. 15 p.

[17] Artificial Intelligence Strategy. URL: https://www.ki-strategie-deutschland.de/home.html

[18] Germany: Artificial Intelligence Strategy. European Commission. 9 April 2019. URL: https://ec.europa.eu/knowledge4policy/ publication/germany-artificial-intelligence-strategy_en

[19] Made in Germany: Die Industriestrategie 2030. URL: https://www.bmwi.de/Redaktion/DE/Dossier/industriestrategie-2030. html 